\title{
A cohort mortality study of forestry workers exposed to phenoxy acid herbicides
}

\author{
Lois M Green
}

\begin{abstract}
A cohort mortality study was undertaken of forestry workers at a public electrical utility who had worked for six months or more during 1950-82 and who were routinely exposed to herbicides including phenoxy acids. A total of 1222 men with 25274 years at risk experienced 80 deaths. Ascertainment of vital state at the end of follow up was $95.5 \%$. The male population of the province (Ontario) was used as the reference group. Overall, no excess mortality was found in this cohort relative to the reference population. A statistically significant increase in deaths occurred, however, due to suicide $(S M R=210,95 \%$ confidence interval, 95\% CI 105-376) for the cohort as a whole. No deaths were seen due to cancers such as soft tissue sarcoma and non-Hodgkin's lymphoma that have been cited by other authors as being associated with exposure to phenoxy acid herbicides. Although the cohort is not large, the absence of deaths due to these cancers is consistent with findings from other studies with sufficient numbers to allow examination of specific risks. The cohort is still young, however, and at the end of follow up most had not reached an age when increased incidence of cancer would normally be expected.
\end{abstract}

Phenoxy acid herbicides comprise a large part of vegetation management programmes in Canada. Several epidemiological studies have linked exposure to these herbicides with specific cancers such as soft tissue sarcomas and non-Hodgkin's lymphomas. ${ }^{1-4}$

A cohort mortality study was undertaken at a public utility (Ontario Hydro) that is responsible for the generation, transmission, and distribution of electricity to the province. The group under study belonged to the forestry trade. The workers use herbicides including phenoxy acids for brush control

Health Services Department, Ontario Hydro, 700 University Avenue, Toronto, Ontario, Canada M5G 1 X6

L M Green and line clearing along rights of way of power transmission and distribution lines. Concern regarding the possible associations with cancer and exposure to phenoxy acid herbicides prompted the investigation.

Control of vegetation is an integral part of forestry activities at this utility with herbicide application accounting for most of the control programme since 1950. Brush control and line clearing are performed throughout the year and although frequency varies seasonally, most forestry workers are exposed to herbicides on a weekly basis throughout the year. In the summer foliar application is province wide whereas in the colder months, basal sprays and stump treatments are routine. Exposure to herbicide occurs by breathing the aerosols or by direct contact either from touching recently sprayed vegetation or spray equipment; key factors affecting exposure include weather conditions, the height of brush and terrain, and the type of spraying operation.

Although measurements of personal exposure were not made until 1980 , it can be assumed that failure to wear protective equipment and poor work practices in the $1950 \mathrm{~s}$ and 1960s resulted in exposures to herbicides that were high and that were certainly greater than those likely to be experienced by most members of the general population. The work activities of this occupational group also indicate that exposure to herbicides may be regarded as proportional to duration of employment in the forestry trade at the company.

Table 1 gives a list of herbicides that were used during the period under study. Not all herbicides were used over the entire study period; 2,4 -dichlorophenoxyacetic acid (2,4-D) and until March 1979, $2,4,5$-trichlorophenoxyacetic acid $(2,4,5-T)$ were the most commonly used. Work with phenoxy acid herbicides increased steadily after 1950 because of the need to control greater land area under new lines, and because this means of vegetation management was the most labour and cost efficient. In a 10 year period, the amount of active ingredient of phenoxy acid herbicide used increased by almost $50 \%$.

The exact 2,3,7,8-tetrachlorodibenzo-para-dioxin (TCDD) content of the 2,4,5-T used within the company was not known, but in 1974 the permissible concentration of TCDD in 2,4,5-T registered in Canada was less than $0.5 \mathrm{ppm}$. This was reduced to 
Table 1 Herbicide use within Ontario Hydro

\begin{tabular}{|c|c|}
\hline $\begin{array}{l}\text { Chemical families of herbicides } \\
\text { (generic/trade name) }\end{array}$ & $\begin{array}{l}\text { Approximate } \\
\text { period of use }\end{array}$ \\
\hline $\begin{array}{l}\text { Phenoxy acids: } \\
\text { 2,4-D (weed spray) } \\
\text { 2,4-D + 2,4-DP (Desormone; Silvaprop; } \\
\text { Diphenoprop) } \\
\text { 2,4,5-T } \\
\text { 2,4-D + 2,4,5-T (Brushkill) } \\
\text { 2,4,5-TP (Silvex, Kuron) } \\
\text { Atrazine + 2,4-D } \\
\text { Picloram/2,4-D (Tordon 101) }\end{array}$ & $\begin{array}{l}1950-82 \\
1979-82 \\
1950-79 \\
1950-79 \\
1952-79 \\
1973-82 \\
1965-82\end{array}$ \\
\hline $\begin{array}{l}\text { S-Triazines: } \\
\text { Atrazine } \\
\text { Simazine (Simmaprim) }\end{array}$ & $\begin{array}{l}1970-82 \\
1970-82\end{array}$ \\
\hline $\begin{array}{l}\text { Substituted urea: } \\
\text { Dioxin (Karmex) } \\
\text { Monuron (Ureabor; Telvar "W") } \\
\text { Tebuthiuron (Spike) }\end{array}$ & $\begin{array}{l}1955-82 \\
1950-73 \\
1978-82\end{array}$ \\
\hline $\begin{array}{l}\text { Other: } \\
\text { Aminotrizole (Amitrol) } \\
\text { Ammonium sulphamate (Amate) } \\
\text { Arsenic trioxide } \\
\text { Bromacil (Hyvar) } \\
\text { Dicamba (Banvel; Dycleer) } \\
\text { Fosamine ammonium (Krenite) } \\
\text { Glyphosate (Roundup) } \\
\text { Maleic hydrazide (MH 30) } \\
\text { Paraquat (Gramoxone) } \\
\text { Picloram (Tordon 10K) } \\
\text { Sodium TCA } \\
\text { Stump spray }\end{array}$ & $\begin{array}{l}1968-82 \\
1950-71 \\
1952-4 \\
1958-82 \\
1973-82 \\
1981-2 \\
1975-82 \\
1970-5 \\
1963-82 \\
1965-82 \\
1950-82 \\
1950-82\end{array}$ \\
\hline
\end{tabular}

$\star^{\star}$ Relative to study period.

$0.1 \mathrm{ppm}$ in 1975 and was required to be undetectable with analytical methodology that was sensitive to concentrations of $0 \cdot 1 \mathrm{ppm}$ TCDD. Before 1974, TCDD content of 2,4,5-T may have been $60-$ $120 \mathrm{ppm}$. In Canada currently registered 2,4-D must have a total dioxin content of no more than 30 parts per billion (ppb) and no more than $10 \mathrm{ppb}$ of any dioxin isomer. ${ }^{5}$ Because of a different formulation process, TCDD is not expected to occur in 2,4-D, but the legislative requirement is that it must be undetectable at a detection limit of $1 \mathrm{ppb}$.

By the nature of the routine duties of the forestry workers at this utility, employment during the period of study may be considered synonymous with exposure to phenoxy acid herbicides. The object was to determine whether exposure to phenoxy acids in this group of workers was associated with a mortality experience different from that of the total male population of Ontario.

\section{Subjects and methods}

A cohort of 1222 workers was identified who had worked six months or more in the forestry trade at a public utility (Ontario Hydro) at some time during the period 1 January 1950 to 31 December 1982 . The cohort was identified from records within the company. The follow up period coincided with the period of ascertainment-namely, 1950-82 and was accomplished using internal company records, drivers' licence records (Ministry of Transportation and Communications) and the Canadian Mortality Data Base (Statistics Canada). Vital state was verified only from official sources. For all deaths but one, the underlying cause of death was obtained from the official death certificate. Cause of death and the International Classification of Diseases (ICD) code were recorded as stated on the death certificate to maintain comparability with the statistics used for the reference population. For one person, only the fact of death could be confirmed from official records and the cause of death was obtained from other contacts.

Person-years at risk were calculated with a program based on the standard person-years approach.$^{67}$ Expected numbers of deaths were derived from Ontario provincial death rates for males using 15 five year age groups and seven calendar periods centred on the official five year censuses. Standardised mortality ratios (SMRs) were calculated for main ICD cause of death categories and for suicides, lung cancer, and stomach cancer. Tests of statistical significance were applied assuming that the observed deaths had a Poisson distribution, the mean and variance of which were equal to those for the expected number. The $95 \%$ confidence intervals (95\% CI) were calculated according to Byar's formula. $^{8}$

\section{Results}

Ascertainment of vital state was complete for $95.5 \%$ of the cohort. Fifty five members were lost to follow up after a mean duration in the forestry trade of $4 \cdot 2$ years.

Of the 1222 cohort members, age specific personyears could not be calculated for two because of the unavailability of birth dates. Therefore, the personyears calculation for the cohort includes 1220 members who contributed 25274 person-years during the 33 year follow up. The employment state of the cohort as of the end of follow up is indicative of the trade's stability, most being still employed as foresters (table 2).

Sixty per cent of the cohort has been followed up for 20 years or more with the mean length of follow

Table 2 Employment state by duration in forestry trade

\begin{tabular}{lrrr}
\hline & \multicolumn{3}{c}{ Years in forestry trade } \\
\cline { 2 - 4 } $\begin{array}{l}\text { Employment state as of } \\
\text { 31 December 1982 }\end{array}$ & $<5$ & $5-14$ & $\geqslant 15$ \\
\hline Active employment in forestry trade & 99 & 182 & 260 \\
Active employment elsewhere in & 34 & 100 & 69 \\
$\quad$ corporation & 1 & 3 & 39 \\
Retired & 156 & 117 & 27 \\
Left service & 21 & 18 & 41 \\
Deceased & 39 & 16 & $\frac{436}{2}$ \\
Vital state unknown & 350 & 436 & 436 \\
\hline
\end{tabular}


up equal to 21 years (table 3 ); the main contributors are those cohort members with a long duration in the forestry trade. For the 361 cohort members who worked 20 years or more, the average duration in the trade was 28.6 years with a range of $20-46$ years. About $30 \%$ of the person-years at risk are allocated where time since first entry to the forestry trade is 15 years or longer and years employed in the trade exceeds 10 (table 4).

The 80 deaths identified for the period 1950-82 contributed to an SMR of 94 for mortality from all causes indicating that this cohort experienced an overall mortality lower than that for men of corresponding age in the general population of Ontario, but not significantly so. This was also the case for mortality from circulatory diseases, diseases of the nervous system, respiratory system, genitourinary system, and digestive system (table 5 ).

Seventeen deaths occurred due to malignant neoplasms (table 6). One neoplasm, acoustic neuroma, was benign and death was due to a complication of therapy. Inspection of the death certificate for one other cohort member showed that the cause of death, bladder cancer, was incorrectly coded. The ICD code applied by the vital statistics official to the underlying cause reflected a complication of the treatment of the disease (abdominal wall fistula) as probably the underlying cause of death. Due to the small number of deaths for each type of cancer, expected numbers were calculated only for lung and stomach cancer. No significant excesses in cancer

Table 3 Duration of follow up and employment state

\begin{tabular}{lrrrr}
\hline \multirow{2}{*}{$\begin{array}{l}\text { Employment state as of } \\
\text { 11 December 1982 }\end{array}$} & \multicolumn{3}{c}{ Years of follow up } & \\
\cline { 2 - 5 } & $<10$ & $10-19$ & $\geqslant 20$ & Total \\
\hline $\begin{array}{l}\text { Active employment in forestry } \\
\quad \text { trade }\end{array}$ & 187 & 116 & 238 & 541 \\
$\begin{array}{l}\text { Active employment elsewhere in } \\
\quad \text { corporation }\end{array}$ & 8 & 23 & 172 & 203 \\
$\begin{array}{l}\text { Retired } \\
\text { Left service }\end{array}$ & 16 & 53 & 231 & 43 \\
Deceased & 18 & 14 & 48 & 80 \\
Vital state unknown & 44 & 8 & 3 & 55 \\
Total & 273 & 214 & 735 & 1222 \\
\hline
\end{tabular}

Table 4 Distribution of person-years by duration of employment in the forestry trade and time since first exposure

\begin{tabular}{|c|c|c|c|c|c|}
\hline \multirow{2}{*}{$\begin{array}{l}\text { Duration in } \\
\text { forestry trade (y) }\end{array}$} & \multicolumn{5}{|c|}{ Time since first exposure } \\
\hline & $<10$ & $10-14$ & $15-19$ & $\geqslant 20$ & Total \\
\hline $\begin{array}{l}<5 \\
5-9 \\
10-14 \\
\geqslant 15 \\
\text { Total }\end{array}$ & $\begin{array}{l}6289.0 \\
3926.9 \\
- \\
- \\
10215.9\end{array}$ & $\begin{array}{r}860.6 \\
636.9 \\
2809.4 \\
-\quad \\
4306.9\end{array}$ & $\begin{array}{r}719.5 \\
528.3 \\
579 \cdot 2 \\
1957 \cdot 8 \\
3784.8\end{array}$ & $\begin{array}{r}1055 \cdot 1 \\
676.0 \\
839.8 \\
4395.8 \\
6966.7\end{array}$ & $\begin{array}{r}8924 \cdot 2 \\
5768 \cdot 1 \\
4228.4 \\
6353.6 \\
25274.3\end{array}$ \\
\hline
\end{tabular}

Table 5 Observed (Obs) and expected (Exp) deaths, $S M R s$, and $95 \%$ CIs for major causes of death *

\begin{tabular}{lccc}
\hline Cause of death & Obs & Exp & $S M R(95 \%$ CI) \\
\hline All causes & 80 & 85.02 & $94(75-117)$ \\
Diseases of circulatory system & 27 & $29 \cdot 39$ & $92(61-134)$ \\
External causes (accidents) & 25 & 23.04 & $109(70-160)$ \\
Neoplasms (malignant and benign) & 18 & 16.48 & $109(65-173)$ \\
Diseases of nervous system and & 2 & $2 \cdot 06$ & $97(11-350)$ \\
$\quad$ sense organs & 3 & 3.3 & $91(19-265)$ \\
Diseases of respiratory system & 4 & 4.54 & $88(24-225)$ \\
Diseases of digestive system & 1 & 1.00 & $100(1-556)$ \\
Diseases of genitourinary system & 1 & &
\end{tabular}

^Male Ontario population rates as a standard.

Table 6 Numbers of deaths due to malignant neoplasms

\begin{tabular}{lc}
\hline Type of cancer & No (1950-82) \\
\hline Lung & 5 \\
Stomach & 2 \\
Pancreas & 2 \\
Colon & 2 \\
Bladder & 1 \\
Thyroid & 1 \\
Leukaemia (acute myelogenous) & 1 \\
Prostate & 1 \\
Tongue & 1 \\
Kidney & 1 \\
Total & 17 \\
\hline
\end{tabular}

* One other death was coded on the official death certificate to "diseases of the digestive system" but bladder cancer should be regarded as the underlying cause of death.

mortality were seen: there were five observed deaths from lung cancer $v 4.57$ expected and two observed deaths from stomach cancer $v 1.05$ expected. The SMR of 210 for suicide with 11 observed deaths $v$ $5 \cdot 25$ expected was the only statistically significant finding $(\mathrm{p}=0 \cdot 04)$.

\section{Discussion}

As expected, this cohort shows evidence of the healthy worker effect. The low SMRs for mortality due to all causes and diseases of the circulatory system reflect the selection and survival of healthy and fit people into the physically demanding forestry occupation. ${ }^{-\mathrm{i} 2}$

A slight but non-significant excess of deaths occurred for all causes of mortality for those employed less than five years, which is a finding characteristic of most occupational cohorts. ${ }^{13}$

No clear explanation exists for the significant twofold excess in suicides or the fact that suicide risk decreases with years spent in the forestry trade. With one exception, there was no personal medical information which might help to explain this excess. One suicide death might have been accounted for by the cohort member's medical history that included a progressively disabling neurological disease. 
Hogstedt and Westerlund, ${ }^{14}$ in their cohort study of forestry workers in Sweden, reported an increase in violent deaths. Six of the 12 "violent deaths" were suicides. The standardised proportionate mortality ratios and standardised mortality odds ratios calculated by Kogan and Clapp ${ }^{15}$ in their study of Massachusetts Vietnam veterans showed statistically significant excesses for suicides. Other studies relating either to exposure to phenoxy acid herbicide or to forestry work have not shown such excesses but few were cohort investigations in which a complete picture of the range of outcomes was obtained. In my study, the suicides appeared to be clustered in the period 1957-67 and in view of this, consideration might be given to the theory of imitative behaviour. ${ }^{16}$ Alternatively, a different explanation is worthy of speculation. Although it may seem that increased risk of suicide would be unrelated to forestry work or more specifically to exposure to phenoxy acid herbicide, some published reports describe neurological toxicity associated with exposure to phenoxy acid herbicides. A farming student committed suicide by ingestion of the dimethylamine salt of 2,4-D; the necropsy examination showed degenerative ganglion cell changes in the brain, although the substance did not appear to concentrate in the brain. The authors, ${ }^{17}$ with the provision that the cerebral changes were not due to anoxia, suggested that the nervous tissue must have been extremely sensitive to this substance. Oliver $^{18}$ described personality changes and neurological disturbances in two laboratory workers who were exposed to 2,3,7,8-tetrachlorodibenzo1,4-dioxin. In a health survey of workers in a factory which made $2,4,5-T$, a correlation was found between the severity of chloracne, known to be associated with dioxin exposure, and a high score on the manic scale of the Minnesota multiphasic personality inventory. ${ }^{19}$ It is therefore reasonable to consider whether neurological toxicity associated with exposure to phenoxy acid herbicide might have psychiatric manifestations such as suicide..$^{20}$ Whether the increased risk of suicide is a chance finding resulting from testing for multiple hypotheses or whether it is real merits further study.

The knowledge that this study was being conducted prompted an inquiry from one cohort member who had recently experienced a basilar artery thrombosis with infarction of the occipital lobe at age 53 years. Both he and his physician raised the question of a causal relation with exposure to herbicides. The documented exposure for this cohort member while employed with the company was $2,4,5-T$, arsenic trioxide, and monuron. The death of one member of the cohort, at 44 years of age was also due to basilar artery thrombosis. Such a diagnosis is uncommon at those ages and although the study does not permit a full determination of incidence of specific health outcomes, the question of basilar artery thrombosis as a late complication of exposure to phenoxy acid herbicides is worthy of consideration. At least one report exists citing changes in the central nervous system due to an unusual type of severe atherosclerosis of the cerebral arteries in a 57 year old subject working in production of sodium 2,4,5-trichlorophenoxyacetate and butyl ester of 2,4,5-trichlorophenoxyacetate acid, and with documented chloracne linked to chronic TCDD intoxication. ${ }^{21}$

Although this investigation was prompted by concern regarding findings in Sweden of soft tissue sarcomas and exposure to phenoxy acid herbicides, ${ }^{1}$ no deaths from cancer of this type were found. Nor did the study show any deaths due to non-Hodgkin's lymphoma, which other authors have shown to be associated with exposure to this type of herbicide. ${ }^{23}$ Because of the small size of the cohort, the statistical power to detect real increases in risk of nonHodgkin's lymphoma or soft-tissue sarcoma, however, is low. This study only had sufficient statistical power $(84 \%)$ to detect a sevenfold increase in non-Hodgkin's lymphoma. For soft tissue sarcoma, the power was $80 \%$ to detect a 27 -fold increase, with two observed deaths. Despite this, the absence of deaths due to soft tissue sarcoma or nonHodgkin's lymphoma is consistent with findings in other studies ${ }^{22-24}$ that, as described by Johnson, ${ }^{25}$ had sufficient numbers to examine the risks for these cancers.

The cohort is characterised by a group of young men who entered the forestry trade in the 1950 s and who have mostly remained in this trade group throughout their career. Many of the cohort members are only now approaching the age when mortality would be expected. At the end of follow up, $96 \%$ of the person-years experience was contributed by subjects less than 55 years of age with an average age at the end of follow up of 43 years. It would therefore still be possible for an excess of cancer deaths to be observed in further follow up. Although the follow up period of 33 years might appear adequate, the results can only be interpreted with caution.

Although not directly relevant to the purpose of this investigation, it is of interest that only one death was due to acute myelogenous leukaemia. An increased risk of this leukaemia subtype has been found in occupational groups thought to be exposed to electromagnetic fields. ${ }^{26-28}$ The primary function of the forestry trade is to perform line clearing adjacent to Ontario Hydro lines and associated apparatus and linemen at this utility work close to both transmission and distribution lines. Movement between the forestry and line trade is not uncommon. Leukaemia is a cancer with a relatively short latent period, and if a leukaemogenic risk associated with electromagnetic fields surrounding power lines exists, some evidence might be expected even in a small cohort.

In summary, the results agree with findings from 
other studies in which no association was found between phenoxy acid herbicide exposure and certain cancers. The cohort is small, however, and extended follow up is required. The excess of suicides in the cohort was an unexpected finding and prompts speculation regarding the biological plausibility of the result in relation to exposure to herbicide. Evidence from the epidemiological studies completed thus far cannot discount the carcinogenic potential of phenoxy acid herbicides. It would seem from this study, however, that if such a risk exists, it is low and requires a long latent period.

Consultation on the analysis was provided by $\mathrm{Mr} \mathrm{Jim}$ Julian, a statistician with McMaster University, Hamilton, Ontario.

1 Eriksson M, Hardell L, Berg NO, Moller T, Axelson O. Softtissue sarcomas and exposure to chemical substances: a case referent study. $\mathrm{Br} J$ Ind $\mathrm{Med} 1981 ; 38: 27-33$.

2 Hardell L, Eriksson M, Lenner P, Lundgren E. Malignant lymphoma and exposure to chemicals, especially organic solvents, chlorophenols, and phenoxy acids: a case control study. Br J Cancer 1981;43:169-76.

3 Hoar SK, Blair A, Holmes FF, et al. Agricultural herbicide use and risk of lymphoma and soft-tissue sarcoma. J $\mathrm{Am} \mathrm{Med}$ Assoc 1986;256:1141-7.

4 Woods JS, Polissar L, Sevenson RK, Henser LS, Kulander BG. Soft tissue sarcoma and non-Hodgkin's lymphoma in relation to phenoxy herbicide and chlorinated phenol exposure in western Washington. J Natl Cancer Inst 1987;78:899-910.

5 Agriculture Canada memorandum to registrants $R-1-216$, April $15,1983$.

6 Case RAM, Lea AJ. Mustard gas poisoning, chronic bronchitis and lung cancer. British Journal of Preventive and Social Medicine 1955;9:62-72.

7 Doll R. Mortality from lung cancer in asbestos workers. $\mathrm{Br} J$ Ind Med 1955;12:81-6.

8 Breslow NE, Day NE. Statistical methods in cancer research. Vol II. The design and analysis of cohort studies. Lyon: International Agency for Research on Cancer, 1987.

9 Fox AJ, Collier PF. Low mortality rates in industrial cohort studies due to selection for work and survival in the industry. British Journal of Preventive and Social Medicine 1976;30: 225-30.

10 Koskela R-S, Jarvinen E, Kolari PJ. Effect of cohort definition and follow-up length on occupational mortality rates. Scand J Work Environ Health 1984;10:311-6.
11 Pearce $\mathrm{N}$, Checkoway $\mathrm{H}$, Shy C. Time-related factors as potential confounders and effect modifiers in studies based on an occupational cohort. Scand $J$ Work Environ Health 1986;12:97-107.

12 Monson RR. Observations on the healthy worker effect. $J$ Occup Med 1986;28:425-33.

13 Doll R. Occupational cancer: a hazard for epidemiologists. Int J Epidemiol 1985;14:22-31.

14 Hogstedt C, Westerlund B. Cohort study of the fatality causes in forest workers exposed and unexposed to phenoxy acid preparations. Lakartidningen 1980;77:1828-31. (Translated for EPA by Literature Research Corporation.)

15 Kogan MD, Clapp RW. Mortality among Vietnam veterans in Massachusetts, 1972-1983. Boston: Massachusetts Office of Commissioner of Veterans Services, Agent Orange Program, Massachusetts Department of Public Health, Division of Health Statistics and Research, 1985.

16 Phillips DP. The influence of suggestion on suicide: substantive and theoretical implications of the Werther effect. American Sociological Review 1974;39:340-54.

17 Nielsen K, Kaempe B, Jensen-Holm J. Fatal poisoning in man by 2,4-dichlorophenoxyacetic acid (2,4-D); determination of the agent in forensic materials. Acta pharmacologica et toxicologica 1965;22:224-34.

18 Oliver RM. Toxic effects of 2,3,7,8-tetrachlorodibenzo-1,4dioxin in laboratory workers. $\mathrm{Br} J$ Ind $\mathrm{Med}$ 1975;32:49-53.

19 Poland AP, Smith D, Metter G, Possick P. A health survey of workers in a 2,4-D and 2,4,5-T plant. Arch Environ Health 1971;22:316-27.

20 Green LM. Suicide and exposure to phenoxy acid herbicides. Scand $J$ Work Environ Health 1987;13:460.

21 Pazderova-Vejlupkova J, Lukas E, Nemcova M, Pickova J, Jirasek L. The development and prognosis of chronic intoxication by tetrachlorodibenzo-p-dioxin in men. Arch Environ Health 1981;36:5-11.

22 Coggon D, Pannett B, Winter PD, Acheson ED, Bonsall J. Mortality of workers exposed to 2-methyl-4-chlorophenoxyacetic acid. Scand J Work Environ Health 1986;12:448-54.

23 Royal Commission on the use and effects of chemical agents on Australian personnel in Vietnam. Final report, cancer Canberra: 1985. (Parliamentary paper 291.)

24 Wiklund K, Dich J, Holm L. Soft-tissue sarcoma risk in Swedish licensed pesticide applications. J Occup Med 1988;30:801-4.

25 Johnson ES. Association between soft-tissue sarcomas, malignant lymphomas and phenoxy herbicides/chlorophenols: evidence from occupational cohort studies. Fund Appl Toxicol 1990;14:219-34.

26 Calle E, Savitz D. Leukaemia in occupational groups with presumed exposure to electrical and magnetic fields. New England Journal of Medicine 1985;313:1476-7.

27 Milham S. Mortality from leukaemia in workers exposed to electrical and magnetic fields. New England Journal of Medicine 1982;307:249.

28 Wright WE, Peters JM, Mack M. Leukaemia in workers exposed to electrical and magnetic fields. Lancet 1982;ii:1160-1.

Accepted 10 September 1990 